\title{
Columbia's Two-Track System
}

The two-track system of professional ranks and position categories at the Columbia University Libraries was implemented in 1973-74, developing from an earlier staff committee recommendation. The origins of the system are directly related to the response of the librarians to the "Columbia Crisis of 1968" and to the issue of faculty status. Columbia's statutory recognition of librarians as academic officers of the unicersity as early as 1911 clearly. influenced both the university's responsiveness to the development of the system and the staff s concern for improving the status of librarians and developing meaningful criteria for the recognition of professional distinction.

HE GENERAL OUTLINE of professional staff organization at the Columbia University Libraries includes two parallel elements, (1) a system of professional ranks and (2) a system of position categories. With the exception of a few senior officers, each professional librarian holds a position that is classified into one of five categories on the basis of the degree of administrative or policymaking responsibility involved. In addition to a position assignment, each professional staff member holds a title denoting professional rank, which is independent of the position and which reflects the level of professional achievement of the individual, largely as seen by peers, that is, librarians within the Columbia system and other professional colleagues.

One element of this two-track system, which was implemented in 1973-74, was developed in response to the "Columbia Crisis of $1968^{\prime \prime}$ and the issue of faculty status for academic librarians. Prior to the development and implementation of these systems, Columbia had a traditional one-track position classification scheme for librarians.

Although Columbia was only one of a number of universities that suffered violent student disruptions in the late 1960s and

Frederick Duda is assistant university librarian for personnel, Columbia Unicersity Libraries, New York City. early 1970 s, there were certain internal factors that contributed to the intensity of the crisis and culminated in the still controversial police "bust" the night of April 29-30, 1968.

As The Cox Commission Report points out, "the administration of Columbia's affairs too often conveyed an attitude of authoritarianism and invited distrust." 1 Friction between the university administration and the faculty, indifference to student opinion and needs, a faculty structure which discouraged involvement in decision making, as well as the lack of a university senate, were internal realities that, coupled with the social unrest of the times, made Columbia ripe for revolution. Following the crisis, Columbia embarked upon a major study and restructuring, a process that eventually led to a more responsive system of governance.

Librarians quite early articulated their concern for an active role in the effort to reorganize the university. At a general meeting of the department and division heads on May 7, 1968, Richard H. Logsdon, director of libraries from 1953 to 1969 , responded to this concern by establishing the study committee, which was created to make recommendations concerning the role of the libraries in the restructuring process.

Initially, the study committee concentrated on university-wide issues and suc- 
cessfully convinced the executive committee for the restructuring of the university that librarians should have representation on the first university senate, which was established at Columbia in May 1969. The other two areas of primary concern were the nature of the relationships of the libraries with students and faculty and the status of librarians.

In 1969-70, the study committee was reconstituted as the representative committee of libraries and completed its work on the question of the role and status of librarians within the university. The representative committee of librarians completed this inquiry when it submitted two documents to Warren J. Haas, who became university librarian in January 1970: "A Recommended System of Professional Levels," September 17, 1970, and "Draft Proposal for Peer Evaluation," October 29, 1971.

The evolution of these recommendations for the implementation of a one-track professional system of ranks to the current twotrack system occurred over a period of several years and was influenced by several factors. Before exploring these factors, however, the reasons why collective bargaining and faculty status were not considered viable systems of organization should be noted.

\section{Collective Bargaining AND FACULTY STATUS}

Gwendolyn Cruzat's observation on why some librarians in research libraries have rejected both collective bargaining and faculty status is applicable to the Columbia situation:

The academic librarians in such environments have been accorded, in most instances, status as librarians. That is, they play a role in the governance of many of these institutions by having representation in the institutions' senates or other policy making bodies. They also serve on the standing and special committees appointed by these bodies. There are also institutions, such as Harvard University, where librarians decided to work for a kind of status different from that of the faculty. ${ }^{2}$

As early as 1911, the Columbia University Charters and Statutes defined librarians as a distinct group allied with the faculty in accomplishing instructional and research objectives. The 1911 Statutes not only defined librarians as academic staff but also equated librarian titles to the four professional ranks. ${ }^{3}$

The nature of the status of librarians at Columbia was clarified in subsequent revisions of the Statutes so that it was understood that librarians ranked with officers of instruction with respect to university benefits and privileges. Within this framework the university librarian, with authorization from the executive vice-president for academic affairs and provost, has the flexibility to develop a system of organization for the professional staff that will both meet library service objectives and provide mechanisms for recognizing and rewarding librarians on the basis of their functional responsibilities and individual contributions.

The consensus of librarians at Columbia in the late 1960s was that faculty status implied adherence to faculty standards for appointment, promotion, and tenure and that such on adherence would lead to an obfuscation of their basic role as academic librarians. Although they believed that "there are several levels of librarianship, with a range comparable to the range among faculty," 4 they also believed that they should develop their own model rather than adopt one which neither reflected their functional roles nor accommodated their conception of distinction.

\section{Evolution of the Two-Track System}

The system of professional ranks and the peer review process recommended by the representative committee of librarians in 1970 and 1971 was similar to systems in existence or under development at a number of institutions. The evolution from this system to the current two-track system occurred over a period of almost five years. This seems to be a relatively long time; however, a number of other activities at Columbia during this period both affected the priority given to the system and influenced its final form.

During the early 1970s higher priorities had to be given to the development and implementation of a new classification scheme for the recently unionized supporting staff, as well as to training supervisors in contract and grievance administration. It was during 
this period, also, that the libraries developed its goals and procedures for the university's first affirmative action plan, which was accepted by the Office of Civil Rights in December 1972.

Another key activity at Columbia at the time was the Booz, Allen, and Hamilton management study, which was sponsored by the Association of Research Libraries in cooperation with the American Council on Education. This study, which was completed in 1972, was one of the key influences on the development of Columbia's two-track system. The other primary influence was a combination of staff input and Haas' concepts of the nature of academic librarianship.

In analyzing the staff structure at Columbia, the management study made the following observation:

Evaluation of present staffing patterns at Columbia in terms of principles developed through experience in a variety of institutions that can be applied to research libraries indicates several limitations which should be overcome. Of particular importance to Columbia's ability to cope effectively with future requirements is the inadequacy of present staffing patterns in focusing professional effort and in developing specialized capabilities and career opportunities. Because advancement tends to follow administrative lines, librarians interested in careers in a subject area or professional field are limited in their opportunities for career progression. The present plan tends to force excellent staff into administrative positions as the only channel for advancement in the system. In addition, professionals with responsibility for particular small operating units often perform nonprofessional and clerical tasks to justify their full-time assignment to the position; this, of course, diminishes user access to and utilization of these highly skilled librarians. ${ }^{\text {s }}$

The problem of career progression, which was a concern of many library administrators at the time, was noted by Donald Cameron and Peggy Heim in the compensation surveys they conducted for the Council on Library Resources for 1969-70, 1970-71, and 1972-73. Although Cameron and Heim offered no one solution, they suggested several devices which might resolve the problem. Two of these devices are relevant to the Columbia situation:

Still another way would be to abandon the de- partmental structure altogether. One variation would be to classify professional librarians on some kind of scale which would allow for promotion without administrative responsibility and would reward distinguished service to students and faculty and to learning at large. A second variation would involve a reexamination of academic and professional requirements for initial appointments and for subsequent promotion. In both variations the problem is the establishment of appropriate criteria. ${ }^{6}$

Little consideration was given to abandoning an administrative or departmental structure at Columbia because it was apparent to the library administration and most of the staff that administrative and supervisory responsibilities were integral functions of many positions. This was also observed in the management study, which recommended the development of five classes of librarian positions. ${ }^{7}$

It is difficult to separate Haas' contributions to the development of the two-track system from the input of various members of the staff. Although the management study noted that working relationships and communications at Columbia had "improved through the use of committees, staff meetings, and memoranda," they were still considered inadequate for various reasons, including feelings of distrust among the staff resulting from a lack of involvement in management decisions. ${ }^{8}$ Had there been no management study, it is apparent to those who worked closely with Haas during the eight years he was university librarian at Columbia that there would be more staff involvement in the decision-making process.

\section{ChaRACTERISTICS OF THE SYSTEM OF Professional RANKS}

The system of ranks and peer review at Columbia was established to benefit both the members of the professional staff and the libraries. For the librarian, the plan establishes a mechanism to acknowledge professional growth and accomplishment. The system of ranks provides for recognition of individual merit, quality of performance, and professional and scholarly contributions. Further, it allows each librarian to receive appropriate financial compensation and significant professional advancement without necessarily assuming management responsibility. The evaluation and review proce- 
dures for promotion in rank are intended to help assure that each librarian will be appraised fairly on the basis of stated criteria. These criteria provide guidelines for uniform assessment throughout the library system and facilitate recognition of achievement.

The system is based on the premises that librarianship is a field in which a variety of skills and talents are valued and that the quality of library operations is governed by distinctive professional performance. The system of ranks and the related performance review process encourage individual professional development in the context of library and university objectives and thus are aimed at the development of an effective professional staff of the highest quality to provide excellent library service to the university.

With the exception of the university librarian, each member of the professional staff holds one of four ranks. Initial determination of rank and subsequent promotion are largely governed by a review process conducted by the professional review committee. While the recommendations of this committee are advisory to the university librarian and ultimately to the university administration, the work and judgment of the committee are fundamental to the ranking process. Committee procedures have been carefully established to assure comprehensive and fair reviews while maintaining confidentiality. General descriptions of the four professional ranks follow:

Librarian I. This rank designates the beginning level of librarianship. The title Librarian I is assigned to individuals who have completed the required professional and/or other graduate training, but have little or no pertinent experience in research or academic librarianship.

Librarian II. This is the initial career rank, and individuals promoted to Librarian II are those who have adequately displayed professional skills and perceptions as well as an affinity for academic and research librarianship.

Librarian III. This is the principal professional rank, which it is assumed a majority of staff members will attain. It generally indicates that the individual has mastered the skills and techniques of librarianship, has demonstrated a high level of professional performance, and has made meaningful professional contributions.

Librarian IV. This highest professional rank is re- served for individuals who have made distinctive contributions over a significant period of time to the university libraries and to the profession. Promotion to Librarian IV is exceptional rather than usual.

\section{Criteria for Promotion}

The general criteria for promotion in rank are quality of performance in the area of the candidate's responsibility, as well as the quality of service on library committees and task forces, library instructional activities, professional activities outside the library, research and academic achievement, and participation in university affairs. The criteria are not of equal significance, and the degree of importance given to any one of them may vary from one candidate to another.

It is the intent of the system to foster the professional development of the individual through external activities and the pursuit of advanced degrees in conjunction with, but not at the expense of, fulfillment of responsibilities to the Columbia libraries. Although talents, inclinations, and specialities of individuals and demands of positions may vary, high quality job performance is one criterion which must be met for any promotion.

Advancement in rank is not automatic upon cumulation of years of experience, but is based on appraisal of the performance of each librarian. In promotion from ranks I to II and II to III, job performance is typically the single most important factor. In promotion from ranks III to IV other factors in addition to job performance are given increasing weight. The specific criteria, which are summarized below, are similar to those found at a number of institutions which have either faculty status or comparable ranking systems. ${ }^{9}$

Job Performance. Among the factors considered are: consistency of performance, ability to innovate, initiative, ability to work effectively with others, responsibility, ability to organize work, ability to relate job functions to the more general goals of the library and university, response to criticism, dependability, accuracy, oral and written skills, judgment, professional attitude, adaptability, and leadership.

Library Committees and Instructional Assignments. The quality and extent of contributions made to the solution of library problems through 
service on internal committees, task forces, and the instructional program are considered, even though such service may be unrelated to the individual's primary area of responsibility. Among the factors considered are: fulfillment of basic obligations of attendance and participation, working relations with other members, membership/chairmanship of subcommittees, timely completion and quality of committee assignments.

Professional Activities, Continuing Education, Research, Publications, and Teaching. Meaningful participation in professional activities on local, state, regional, and national levels is considered. Examples of such participation include offices held, awards received, and leadership of seminars and workshops. An individual is expected to continue study and research in fields relevant to librarianship. Involvement in continuing education activities, such as formal courses, seminars and workshops, as well as advanced degrees obtained or in progress will be considered. Professional contributions such as books, articles, book reviews, editorships, bibliographies, handbooks, teaching appointments, and lectures are also considered.

University Service. Consideration is given to relevant university service, such as participation in the work of senate committees, departmental and ad hoc committees, and other university organizations.

Two frequently asked questions addressed to the professional review committee by librarians who were not on the staff when the system of ranks was being developed concern the nature of the peer review process and the element of confidentiality. Both of these elements are critical to the system.

\section{The Nature of the Peer Review Process}

The professional review committee is analogous to and modeled on the ad hoc committees appointed at Columbia by the provost to advise on the faculty tenure recommendations to be made to the president and trustees. ${ }^{10}$ Under the university Statutes, only the university librarian has the authority to recommend to the president and trustees, through the provost, the promotion in rank of officers of the libraries. The university librarian delegates to the professional review committee the responsibility for conducting a peer review and reporting to him or her the results of that review with a recommendation for action.

The term "peer" denotes "one that is of the same or equal standing (as in law, rank, quality, age, ability) with another" (Webster's Third New International Dictionary). "Peer review" therefore implies professional evaluation by colleagues from among one's own ranks. The peers involved in reviewing each candidate are not just members of the professional review committee but all those professional colleagues, both within and outside the libraries, who contribute their thoughtful impressions to the committee, which is responsible for assembling and synthesizing this information.

Since the professional review committee can only be advisory to the university librarian, the "Draft Proposal for Peer Evaluation" developed by the representative committee of librarians in 1971 envisioned from the start a committee appointed by the university librarian. Committee members must have a broad view of the libraries and the profession and be in a position to devote a substantial amount of time to the committee's work. When the system was implemented, a procedure was established by which the representative committee of librarians provides the university librarian with a slate of nominees for membership on the professional review committee when vacancies occur. The university librarian retains the authority to supplement this list to ensure a balanced committee familiar with the widest possible range of library and professional activities.

\section{Confidential Nature of the Process}

The original recommendation of the representative committee of librarians provided: "All relevant documents .... will be kept in strictest confidence. Likewise, all committee discussions and results will be confidential." The models from which this recommendation derives are those of the tenure review procedure for the Columbia faculty and of similar systems at a number of other large research libraries.

Confidentiality is an integral aspect of the faculty review process at Columbia, as it is in most colleges and universities, and is intended to protect the privacy of candidates, while encouraging a rigorous and impartial review in recognizing and rewarding distinction. At the time the peer-review process was being developed, the consensus of the professional staff was that it was essen- 
tial for the documentation assembled by the committee to be held in confidence.

To protect the candidate, the procedures of the professional review committee require that there be evidence of professional contact between the candidate and anyone asked to write a confidential letter, and that the committee, if it asks any, must ask more than one co-worker or subordinate for letters. Each candidate is invited to submit names, and the committee selects additional names, with the total number of letters solicited being related to the range of the candidate's professional activities both within and outside the libraries, and normally increasing for those being considered for promotion to the higher ranks. These procedures were designed to ensure that the committee would not receive a one-sided picture of the job performance and professional activities of a candidate, and that no single letter can determine the outcome of an individual's promotion review.

The documents assembled for the promotion review are accessible only to the professional review committee, the university librarian, and the assistant university librarian for personnel. When the review is completed, the documents are placed in a special locked file for a three-year period and then are destroyed. The only records from the whole promotion review process that are placed in an individual's permanent personnel file, and are therefore accessible to an individual's immediate supervisor, are the letter from the university librarian communicating the decision and the summary statement explaining the reasons.

Although this process was modeled on the procedures for tenure review for faculty at Columbia, there are differences. For example, under the Columbia faculty tenure review system, the candidate does not know who is appointed by the provost to serve on his or her ad hoc committee, what evaluation the dean or department director may have submitted, or who is asked to be a witness or to write a letter. The professional review committee in the libraries is a standing committee whose members are known; the supervisory performance appraisal is given to the librarian who is encouraged to respond in writing. In addition, it has been understood that, while the professional re- view committee carefully protects the confidentiality of all letters submitted as part of the review process, the writers of the letters are free to share them with the candidate should they wish to do so.

\section{IMPLEMENTATION OF THE SYSTEM OF RANKS}

The staff development committee, which was established as part of the general reorganization of the Columbia Libraries in July 1972, was given responsibility for developing proposals for the implementation of the system of ranks. The committee conducted a series of meetings with the staff to discuss materials under development which outlined the philosophy and procedures for the promotion review process. Several modifications were made as a result of these meetings prior to the implementation of the promotion review process, and changes have continued to be made since the system of ranks was fully implemented in 1975-76. (The staff development committee was reconstituted as the professional review committee in July 1975 and charged with carrying forward the system of ranks and peer review.)

The changes made in the system of ranks and peer review included establishing four rather than five ranks, a modification which seemed necessary in order to emphasize that the highest rank is "reserved for individuals who have made distinctive contributions over a significant period of time to the University Libraries and to the profession."11

The development of summary statements to provide candidates with the reasons for promotional decisions and the inclusion of professional supervisees among those who may be contacted for additional documentation were also instituted as a result of suggestions from various members of the professional staff.

Perhaps the most significant modification was the decision not to exclude any librarian from consideration for promotion to the highest rank. There are a number of ranking systems that do have such limitations, that is, individuals in certain positions, such as general cataloging and reference, are normally excluded from the highest rank. The staff development committee felt that such a 
concept was inappropriate at Columbia because it would impose limitations on a large number of librarians performing key bibliographic and service functions. This recommendation was accepted by the university librarian prior to the implementation of the promotion review process.

Following discussions between the staff development committee and the university librarian, it was agreed that the initial assignment of ranks would be handled administratively by the assistant university librarian for personnel. The task was to rank individual librarians as Librarian I, Librarian II/III, or Librarian IV/V. Those ranked as Librarian I generally had less than three years of experience. The distinctions between Librarian II/III and Librarian IV/V were based on a combination of factors: experience, performance, and professional development and accomplishments.

The assistant university librarian for personnel held meetings with supervising librarians in the spring and summer of 1973. After reviewing the criteria for the various ranks and the employment history and activities of individual librarians, supervising librarians were asked to recommend a "broad" rank. In most cases, the recommendations were accepted. In several instances, the university librarian made the final determination. In December 1973 the professional staff were informed of their broad ranks. The broad rankings were subject to appeal; however, none was made.

One year later, staff were informed of their specific ranks. This delay was due in part to the following problems: evaluating long-term staff members; interpreting criteria for the various ranks; and the lack of organization of personnel records. The staff development committee was assigned responsibility for hearing appeals on specific rankings, and one staff member did submit an appeal. After meeting with the individual and reviewing the matter, the staff development committee upheld the original rank.

\section{ASSESSMENT OF THE SYSTEM OF RANKS}

There has been no formal assessment of the system of ranks since the first group of librarians was scheduled for review for promotion in rank in 1975-76. During the four years that the promotion review pro- cess has been in effect, a total of eightynine librarians have been reviewed, and fifty-five (62 percent) were promoted. Through feedback that the library administration and the professional review committee have received from individual staff members and from the representative committee of librarians, there is evidence to indicate that in general the staff considers the system fair and the review process a relevant assessment of significant aspects of professional performance. Since there are mechanisms for modifying the system of ranks and since there are indications that the original objectives of recognizing professional accomplishments within the context of library program and service objectives are being met, it is clear that the system of ranks will remain an integral aspect of Columbia's program for professional librarians.

\section{Characteristics OF THE SySTEM OF Professional Position Categories}

The position classification scheme that evolved as the second track of the system of organization for librarians at Columbia is relatively traditional. As previously indicated, the management study had recommended the development of five classes of librarian positions. The task force charged with developing and defining this scheme, however, was not convinced initially that five classes were sufficient to accommodate the range of activities and responsibilities encompassed by some 130 professional librarians.

The professional classification task force, which was appointed in March 1972 and charged with recommending a classification scheme for professional positions, was not constrained to fit all positions into a fivegrade classification scheme. The maximum number of gradations considered by the task force was eight; the minimum four. What did evolve, however, seemed to reflect the nature of responsibilites at Columbia. It involved five position categories, which were identified through an analysis of various factors that indicated an ascending level of responsibility governed by the extent of administrative duties and/or policy-making responsibilities.

In other words, the task force believed that one track of the system or organization 
of professional staff at Columbia should include recognition and compensation for supervisory and managerial responsibilities.

In developing the five position categories, the professional classification task force adopted a "position-grading" system to determine appropriate categories. ${ }^{12}$ The process involved analyzing each position in relation to other positions and classifying it in terms of level of responsibility. Factors taken into consideration were: complexity of the skills required for the position; nature and extent of relationships with students, faculty, the general public, and academic and administrative components of the university; responsibility for developing and implementing policies, programs, and services; and supervisory or administrative responsibilities (including composition of staff).

In essence, the analysis of these factors indicated that there was an ascending level of position categories governed by the extent of administrative duties and/or policymaking responsibilities.

The system of position categories views the function of a position as constant, although the manner and the effectiveness with which the function is accomplished varies, depending on a number of factors, including the training, background, and experience of the incumbent. Because this is a classification of positions, not of people, the concept of a "beginning" professional position, that is, one budgeted at the current beginning professional salary and usually filled by a recent library school graduate with little or no previous professional experience, is not reflected in the scheme. Theoretically, a "beginning librarian" could be appointed to a position in any category. Realistically, however, such appointments would be unlikely for positions requiring substantial administrative, technical, or program responsibilities.

\section{IMPLEMENTATION OF POSITION CATEgoRies}

The task force appointed to develop the system of professional position categories began its work in March 1972. In December 1973 letters were sent to all librarians informing them of the classification of their positions. To provide input from the staff and to verify the validity of the classifica- tion, a review or appeal process was instituted at the time of the announcements. The appeal process provided each member of the professional staff with the opportunity to meet with the task force to discuss the system in general and to indicate the reasons they felt that their own or other positions had not been properly classified.

At the time of the appeals, there were 135 librarians in positions covered by the classification scheme. Twenty-seven or 20 percent of them appealed their position classification. This was considered high in relation to the number of grievances submitted following the release of the union classification for supporting staff in the spring of 1970 (thirty-two grievances or about 10 percent of the staff). Of the twenty-seven appeals, twenty-five were from librarians whose positions had been classified in Category I. The other two were submitted by individuals whose positions were in Category II.

The task force had a general understanding of the nature of and reasons for the appeals prior to meeting with individual librarians since the appeals had to be stated in writing. It was apparent that some individuals were unclear on the distinctions between the system of ranks and the system of position categories. Although the document describing the classification scheme pointed out that it emphasized "an ascending level ... governed by the extent of administrative duties and/or policy-making responsibilities," individuals either would not accept or did not understand the rationale for this emphasis. When the task force met with individual staff members, therefore, its introductory remarks centered on the nature of position classification schemes and the primary characteristics of the system of position categories. Stress was also given to the differences between rank and position.

The appeals were scheduled and took place in March 1974. In most instances, the task force thought that the discussions were mutually informative and productive. The task force quickly concluded that the description of the functional characteristics of the different position categories could be improved. These revisions included the phrase "this is a classification of positions, not of people," which was necessary to 
underline the distinctions between rank and position category.

The majority of the appeals were made by librarians in cataloging (seven), bibliographer (four), and reference (nine) positions. The characteristic comments made are summarized below:

Catalogers. They generally considered the cataloging function to be on the same level as the bibliographer and reference functions. Several felt that Category I had been watered down by the inclusion of positions which were not "fully realized professional positions." (The task force explained that most of these positions had been or were in the process of being phased out.)

Bibliographers. They considered their functions to be on a higher level than those of catalogers and reference librarians because of the impact of their decisions, their language and subject qualifications, and their fiscal accountability.

Reference Librarians. They did not want to compare their functions to those of bibliographers and catalogers because they felt that they did not have sufficient information about these positions. They indicated concern over the number of reader service positions in Category I and the emphasis on administrative responsibilities in general.

In considering the appeals, the task force also reviewed twenty other positions either because they were comparable to those that had been appealed or because they had been questioned by one or more librarians during the hearings. Forty-seven positions, therefore, were reconsidered before the task force submitted its recommendation to the university librarian. Since the task force could not reach a consensus on certain positions, the university librarian asked the directors of resources, services, and support to serve as an ad hoc subcommittee to provide the task force with additional guidance.

As a result of the appeals, the input from the subcommittee and from the university librarian, four positions were upgraded and two downgraded. The appellants received written responses on August 1, 1974. Thus, the implementation of the system of position categories was completed two years and four months after the task force had been appointed.

\section{ASSESSMENT OF THE SySTEM OF POSITION CATEgoRIES}

There has been no formal assessment of the system of position categories during the past five years. Mechanisms do exist for reviewing positions, and changes are made when responsibilities change significantly. We expect that in the next year we shall be able to conduct a major review of the classification to determine if it continues adequately to reflect the nature of the various responsibilities in the library system.

\section{CONCLUSION}

The two-track system described in this paper evolved during a period of major change in academic librarianship and considerable conflict at Columbia University. A key element in the development of the system of ranks and position categories was the concern of significant numbers of professional librarians at Columbia for a system of organization that would both acknowledge the nature of their duties and responsibilities and their individual contributions in providing a truly high level of library service.

The most significant aspect of the two elements of the staff organization is the system of rank and peer review, which encourages higher standards of performance and provides a means for acknowledging and rewarding such contributions. The success of the system of ranks depends to a large degree on the perceptions and standards of the peer review committee. Fortunately, the various members of the staff development and professional review committees have demonstrated their commitment to the objectives of the system of ranks in their administration of the promotion review process.

The chairs of these committees deserve particular appreciation, not only for their contributions to the ranking system, but also for the text of significant parts of this article: Joyce D. Veenstra (1972-75), Ruth B. Gibbs (1975-76), Carol A. Mandel (197677), Ann L. Wood (1977-78), Pamela W. Darling (1978-79), and Ellen Nagle (197980).

\section{REFERENCES}

1. The Cox Commission Report: Crisis at Columbia (New York: Vintage Books, 1968), p. 193.

2. Gwendolyn Cruzat, "Issues and Strategies for Academic Libraries," in Collective Bargain- 
ing in Higher Education: Its Implications for Governance and Faculty Status for Librarians, Proceedings of a Preconference Institute, sponsored by the Academic Status Committee, Association of College and Research Libraries, American Library Association, San Francisco, June 27 and 28, 1975 (Chicago: American Library Assn., 1976), p. 104 .

3. Columbia University, Charters and Statutes (New York: Columbia Univ., 1911), p. 22.

4. Columbia University Libraries, Study Committee, "Statement of Principles," Columbia University, Oct. 31,1968 . Members of the committee at the time were Donald C. Anthony, C. Donald Cook (chair), Frederick Duda, Paul J.Fasana, Cecile E. Kramer, Carol L. Learmont, Adolf K. Placzek, Edwin Schuck, and Darrow Wood.

5. Organization and Staffing of the Libraries of Columbia University: A Case Study. Prepared by Booz, Allen \& Hamilton, Inc. Sponsored by the Association of Research Libraries in cooperation with the American Council of Education under a grant from the Council on Library Resources (Westport, Conn.: Redgrave Information Resources Corp., 1973), p. 85 .

6. Donald F. Cameron and Peggy Heim, Librarians in Higher Education: Their Compensation Structures for the Academic Year 1972-73 (Washington, D.C.: Council on Library Resources, 1974), p.13-14.

7. Organization and Staffing of the Libraries of Columbia University, p.91.
8. Ibid., p.149-50.

9. Duke University Library, Committee on Professional Staff Structure, "Ranking Structure for Duke University Librarians," Duke University Library, May 20, 1974, revised Oct. 13, 1977, p.4. In developing its criteria for promotion in rank, Columbia drew heavily from the Duke document.

10. Columbia University Libraries, "The System of Professional Ranks," in "Handbook for Librarians," Columbia University Libraries, Professional Review Committee, June 1979. This section, which describes the peer review process and the element of confidentiality, was written primarily by Pamela W. Darling, chair, Professional Review Committee, 197879. She was assisted by Mary Lou Lucy, Ellen Nagle, Thomas T. Watkins, and Elizabeth A. Widenmann.

11. Columbia University Libraries, "The System of Professional Ranks," in "Handbook for Librarians," Columbia University Libraries, Staff Development Committee, Nov. 1973. Members of the Staff Development Committee in 1973-74 were Ann Borsuk, James E. Fall, Ruth B. Gibbs, Judith Herschman, and Joyce D. Veenstra (chair).

12. Columbia University Libraries, "The System of Professional Position Categories,"Columbia University Libraries, Professional Classification Task Force, Dec. 1973. Members of the task force at the time were Laura Cummings, Frederick Duda (chair), Rita G. Keckeissen, Cecile E. Kramer, Helen M. Selesky, and Thomas T. Watkins. 